\title{
IL-2 is involved in immune response of prenatally stressed rats exposed to postnatally stimulation
}

\author{
Eliana G. Falcone ${ }^{a}$, Ana C. Liaudata", Fabrisio E. Alustiza ${ }^{a}$, Nora Mayer ${ }^{a}$, Pablo Bosch ${ }^{a}$, \\ Adriana Vivas ${ }^{\mathrm{b}}$, Hector Gauna ${ }^{\mathrm{a}}$, Nancy Rodríguez ${ }^{\mathrm{a}}$
}

\begin{abstract}
Environmental cues influence growth and development of mammals during prenatal and particularly early postnatal life and can exert long-lasting effects in adult life. High circulating concentration of glucocorticoids during pregnancy (prenatal stress) affects the activity of the hypothalamic-pituitary-adrenal axis (HPA) of offspring and has been linked to alter immune system responses. Early postnatal stimulation (handling) of prenatally stressed animals generates long-term beneficial effects on the reactiveness of the HPA axis and immune system function. The aim of this study was to further investigate the effect of handling on immune response in prenatally stressed male rats and to elucidate a possible relationship with the HPA axis activity. Control and prenatally stressed (PS) offspring by immobilization (IMO) were handled during the first week of life. Animals from both treatments were subjected to acute stress by IMO. Corticosterone (COR) plasma concentration was measured by RIA assay, Tlymphocyte proliferation by $\left[{ }^{3} \mathrm{H}\right]$ thymidine assay and IL-2 levels by direct ELISA technique. Chronic IMO prenatal stress caused an increase in mother plasma COR basal levels. Furthermore, prenatally stressed rats subjected to an acute stress session had lower T cell proliferation and decreased IL-2 release. In addition, early postnatal stimulation reversed the negative effects of prenatal stress on proliferation of T lymphocytes and IL-2 release.

Key words: early stimulation, prenatal stress, hypothalamic-pituitary-adrenal axis, immune system.
\end{abstract}

RESUMEN. Las condiciones ambientales influyen en el crecimiento y desarrollo de los mamíferos durante la vida prenatal, posnatal temprana y pueden ejercer efectos a largo plazo en la vida adulta. Altas concentraciones circulantes de glucocorticoides durante el embarazo (estrés prenatal) afecta a la actividad del eje hipotálamo-pituitario-adrenal (HPA) de la descendencia y se encuentra en relación con alteraciones de las respuestas del sistema inmunológico. La estimulación postnatal temprana de los animales estresados prenatalmente genera efectos beneficiosos a largo plazo en la reactividad del eje HPA y en la función del sistema inmunológico. El objetivo del estudio fue investigar el efecto de las manipulaciones posnatales tempranas sobre la respuesta inmune de ratas machos y dilucidar la posible relación con la actividad del eje HPA. Crías controles y estresadas prenatalmente (PS) por inmovilización (IMO) se manipularon durante la primera semana de vida. Los animales controles y PS fueron sometidos a estrés agudo por la IMO. Los niveles de corticosterona (COR) plasmática se midieron por el ensayo de RIA, la proliferación de linfocitos $\mathrm{T}$ por $\left[{ }^{3} \mathrm{H}\right]$ timidina y los niveles de IL-2 por la técnica de ELISA directa. El estrés prenatal crónico por IMO aumentó los niveles plasmáticos basales de COR en la madre, mientras que las crías PS sometidas a una sesión de estrés agudo posnatal mostraron disminuida la proliferación de células T y niveles menores de IL-2. En conclusión, las estimulaciones postnatales tempranas revirtieron los efectos negativos provocados por el estrés prenatal sobre la proliferación de los linfocitos T y la liberación de IL-2.

Palabras claves: manipulaciones posnatales tempranas, estrés prenatal, eje hipotálamo-pituitario-adrenal, sistema inmune.

\section{INTRODUCTION}

Prenatal environment exerts a profound influence on the development of an organism and may predispose to adaptive disturbances in postnatal life. Stress during pregnancy can alter postnatal physiological responses in the offspring. The degree and extension of these alterations depend upon nature, intensity and duration of the stressor as well as on the stage of gestation at which the stressor is applied (Mayer et al 2011). Stress in the pregnant female produces numerous endocrine changes, chiefly increased in circulating levels of catecholamines (CA), namely epinephrine and norepinephrine and glucocorticoids (GC), all of which are considered the major endocrine mediators

Accepted: 01.03.2017.

a Department of Molecular Biology, School of Exact, Physical-Chemical and Natural Sciences, National University of Río Cuarto, Argentina.

bDepartment of Animal Anatomy, School of Agronomy and Veterinary, National University of Río Cuarto, Río Cuarto, Argentina.

*Corresponding author: AC Liaudat; Ruta 8 Km 601, X5804BYA Río Cuarto, Córdoba, Argentina; cliaudat@ gmail.com of stress-induced immune changes (Maccari et al 2003). Releases of these hormones into the mother's blood stream directly act on fetal development through fetal gene regulation or indirectly through changes in the metabolism of the placenta (Maccari et al 2014). The placenta expresses 11b-hydroxysteroid dehydrogenase type- 2 enzyme, which limits fetal exposure to maternal GC inactivating corticosterone into the metabolite 11-dehydrocorticosterone. Nevertheless, chronic stress during pregnancy significantly reduces activity of this barrier enzyme and increases exposure of the foetuses to maternal glucocorticoids (Benediktsson et al 1997). As a consequence, $\mathrm{GC}$ are able to enter into fetal circulation and affect the ontogeny of hippocampal receptors. This change in GC levels might exert neurotoxic effects (Landifield et al 1996).

Besides, maternal stress induces hyperactivity of the offspring's HPA axis and increases amygdala corticotropinreleasing hormone (CRH) release (Keller-Wood 2015). These changes alter growth rhythm, produce behavioral changes, impair glucose tolerance and modify immune function (Merlot et al 2008). In addition, high levels of maternal CA induce vascular constriction that raises fetal 
placental hypoxia, which in turn, activates the fetal HPA axis and sympathetic nervous system. Consequently, the fetal stress response disrupts and interferes with intrauterine growth (Li et al 2012).

Specifically on immune system function, prenatal stress induces phagocytic dysfunction, decreases NK cytotoxicity and reduces the proliferative response of $\mathrm{B}$ cells (Veru et al 2014). Additionally, Merlot et al (2008) demonstrated that stress during pregnancy induced a size reduction of the thymus and a reduction in the number of circulation total $\mathrm{CD}^{+}$and $\mathrm{CD}^{+}$lymphocytes. Although stress has been reported to affect various functions of the immune system, the mechanisms that mediate these effects remain unclear. Interleukin 2 is considered the primary growth factor for antigen-activated $\mathrm{T}$ lymphocytes being the major inducer for the developmental production of suppressive T regulatory cells (Malek 2003).

Early stimulation or handling $(\mathrm{H})$ of prenatally stressed offspring during the first week of life leads to long-term reduction of the stress response (Fenoglio et al 2005). The effect of $\mathrm{H}$ on HPA axis function in adult rats could be mediated by increased sensitivity of hippocampal neurons to surrounding GC and upregulation of GC receptors. A reduction in the number of $\mathrm{GC}$ receptors is associated with high GC plasma levels, which leads to less adaptive response to stressful situations and to a greater probability of neuronal death in the hippocampus and cognitive deficits (learning and memory) (Ferré et al 1994).

The aim of this work was to investigate the effects of early postnatal stimulation in prenatally stressed male rats on immune response and their relationship to the activity hypothalamic-pituitary-adrenal axis.

\section{MATERIAL AND METHODS}

\section{ANIMALS}

Albino Wistar rats were grown in the National University of Río Cuarto. Five male and 10 female rats were used, the animals were housed in plastic cages in groups of 3 under the following conditions: $12 \mathrm{~h}$ light/12 h dark, $22{ }^{\circ} \mathrm{C}$, constant humidity and water and food ad libitum. Male-female (1:2) were mated overnight and the following morning a vaginal smear was performed and examined microscopically. The first day of pregnancy was determined by the presence of sperm in the smear and the pregnant females were located in separate home cages.

All animals (control, pregnant females and their offspring) were maintained according to the Guide for Care and Use of Laboratory Animals and the experiments were approved by the local Institutional Animal Care Committee.

\section{PRENATAL STRESS}

Chronic stress by IMO was applied to the experimental group of pregnant females. Experimental rats were stressed during two weeks starting on the $6^{\text {th }}$ day of pregnancy (Bertuzzi et al 2003) on a 20 x $20 \mathrm{~cm}$ wood board by taping their limbs to metal mounts as described by Michajloskij et al (1988). Each female was subjected to 30 min stress by IMO three times each week at different times in the mornings of different days (PS). Control female rats were left undisturbed in their home cages (PC). Each mother had an average of 10 live neonates. The male pups from these PS and PC groups were used for subsequent experimentation.

\section{POSTNATAL HANDLING}

Half of litters of stressed and control mothers (n: 36) were handled daily from postnatal day 1 until postnatal day 3 as described by Meaney et al (1987). Briefly, the mother was removed from the home cage before the pups and kept alone in a separate cage. The pups were then picked up and transferred from their home cage to another one containing paper toweling. Separate cages were used for each litter, pups were kept away from the mother for 1 min (between 9-11 a.m. every day) and then, they were returned to their home cage; finally the mother was reunited with pups. This period of separation stimulates maternal handling, which refers to arc-backed nursing, licking and grooming that rat pups receive from their mothers when they were reunited. All handling sessions were conducted in the same room and were supervised by the same researcher.

\section{EXPERIMENTAL DESIGN}

Pregnant rats were randomly allocated to either stressed (PS) or non-stressed control (PC) group (figure 1). Each litter form PS and PC groups was assigned to either handled (PSH or PCH) or non-handled control (PSNH or PCNH). Due to all mother had more than 8 pups per litter, within $24 \mathrm{~h}$ of birth, the litters were culled to eight per mother to minimize the influence of number of offspring on the parameters measured. All groups were housed in the same animal room and pups were kept with their mothers. The offspring were weaned 21 days after birth and housed in groups of four males by litter and left undisturbed until testing. Two 90 day-old male siblings per litter from each group were tested.

\section{CORTICOSTERONE LEVELS}

Blood samples (200-300 $\mu \mathrm{l})$ were collected from control and stressed mothers using the tail clip method (Tuli et al 1995). Samples were taken at 6 and 21 days of pregnancy. For stressed mothers, blood sampling was performed immediately after the acute IMO session (30 $\mathrm{min}$ ). COR levels in plasma were measured by radioimmunoassay (RIA, Armario and Castellanos 1984), using high specificity rabbit antiserum to COR from Bioclin (Cardiff, UK). Assay sensitivity was $10 \mathrm{pg}$ of COR and inter and intra assay coefficients of variability were $<10$ per cent. 


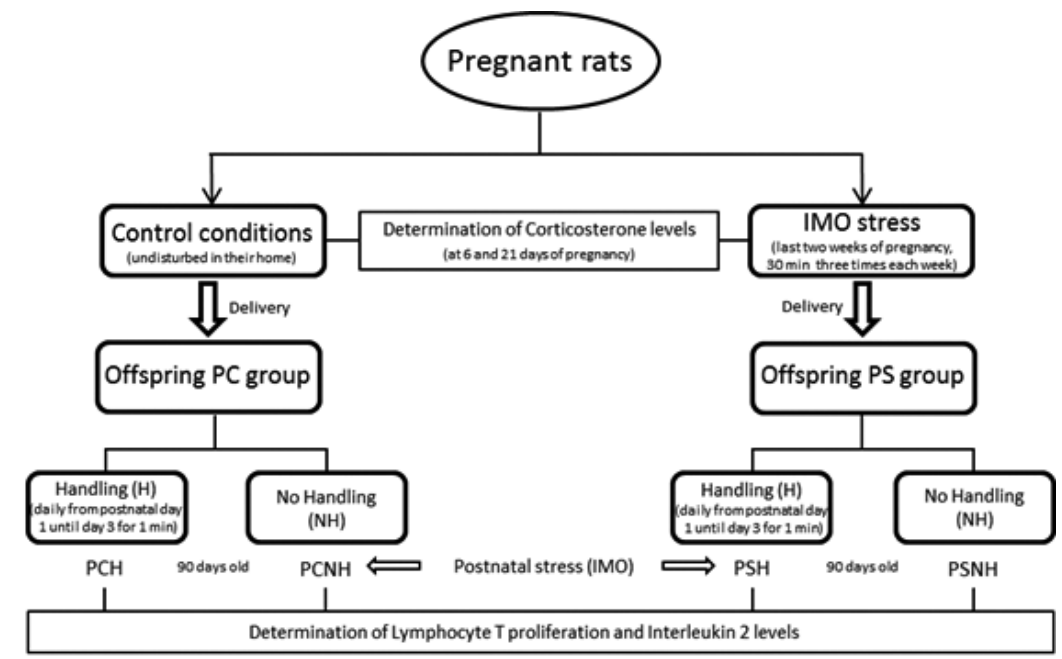

PCNH: offspring of control mothers that did not receive handling treatment $\mathrm{PCH}$ : offspring of control mothers that received handling treatment

PSNH: offspring of stressed mothers that did not receive handling treatment

PSH: offspring of stressed mothers that received handling treatment

Figure 1. Schematic diagram of the experimental groups used in this research.

\section{LYMPHOCYTE T PROLIFERATION}

Adult animals of all groups were sacrificed by decapitation immediately after IMO. For lymphocyte $\mathrm{T}$ cell proliferation, spleen was excised and cell proliferation was determined using the $\left[{ }^{3} \mathrm{H}\right]$ thymidine assay. The spleen cells were seeded in microplate $\left(2 \times 10^{5}\right.$ cells/well $)$ and cultured in RPMI 1640 (Sigma, St. Louis, MO, USA) complete medium (10\% FBS, $25 \mathrm{mM}$ HEPES, $2 \mathrm{mM}$ L-glutamine, $50 \mu \mathrm{M}$ 2-4 mercaptoethanol, $100 \mathrm{U} / \mathrm{ml}$ penicillin, $100 \mu \mathrm{M}$ streptomycin), at $37^{\circ} \mathrm{C}$ a $5 \% \mathrm{CO}_{2}$ in air and $95 \%$ humidity. Twenty four hours later, cells were stimulated with concanavalin A $(2.5 \mu \mathrm{g} / \mathrm{ml}$, Sigma) during $24 \mathrm{~h}$ (Mayer et al 2011). Lympocyte $\mathrm{T}$ proliferation was measured by radioimmunoassay and the counts per million $(\mathrm{cpm})$ was the unit that represent this assay.

\section{INTERLEUKIN 2 LEVELS}

Interleukin 2 (IL-2) concentration in the supernatant of lymphocyte $\mathrm{T}$ cultures stimulated during $24 \mathrm{~h}$ with concanavalin A was determined. IL-2 was measured in culture supernatant by a commercially available enzyme immunoassay kit (ELISA) specific for rat (Bendermeds Systems, San Diego, CA) according to the manufacturer specifications. The absorbance was measured in a microplate ELISA CPD reader. Sample concentrations $(\mathrm{pg} / \mathrm{ml})$ were determined by extrapolation of data from a standard curve.

\section{STATISTICAL ANALYSIS}

Data were analysed using Statistical Software (Tulsa, OK). Differences between prenatally stressed offspring that were handled and not handled were analysed using two-way 2 x 2 ANOVA: the factors were prenatal stress and postnatal handling. Post-hoc comparisons were performed using Duncan's test. The values are expressed as means \pm SEM and $P<0.05$ was considered statistically significant.

\section{RESULTS}

\section{CORTICOSTERONE LEVELS DETERMINATIONS}

We have demonstrated in a previous work (Chen et al 2013) that basal plasma corticosteroid levels in adult prenatally stressed offspring (PSNH and PSH) were higher than in control (PCNH and $\mathrm{PCH})$ groups. With the aim of elucidating if this observation correlated with stressassociated mother COR alterations, we determined plasma COR levels in pregnant rats subjected to stress compared with non-stressed counterparts. As shown in figure 2, COR concentration in plasma of control animals on the 6th day of pregnancy was lower than the same group on the 21st. In contrast, 30 min after stressor application, the hormone concentration markedly increased, being this effect markedly in PS animals on the 6th day.

\section{LYMPHOCYTE T PROLIFERATION}

In our previous work we demonstrated that handling treatment attenuated the observed reduction of $\mathrm{T}$ proliferation associated with prenatal stress in non-stressed rats (Liaudat et al 2012). In this study we further investigated the effect of handling treatment on T lymphocyte proliferation in animals subjected to postnatal stress. Figure 3 shows that acute stress is associated with a reduction of $\mathrm{T}$ 


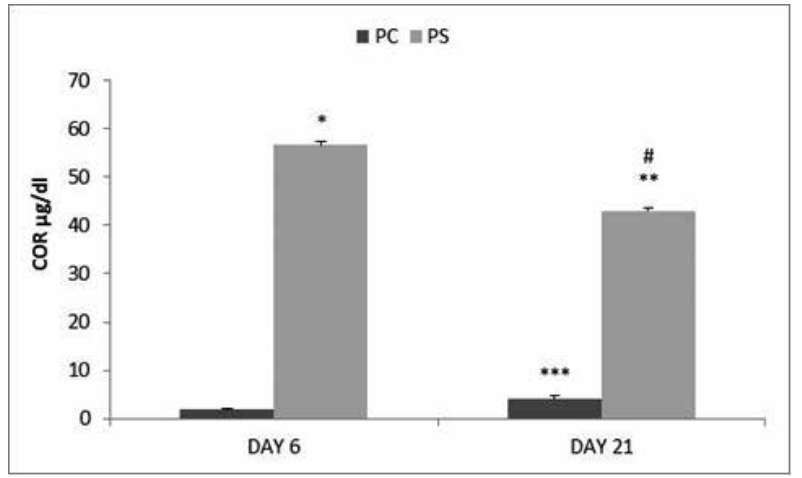

Figure 2. Effect of stress and no stress treatment on pregnant rats COR level. PC day 6 (n: 5), PC day 21 (n: 5), PS day 6 (n: 5), PS day 21(n: 5). Each bar represents the mean \pm SE. $* P<0.05$ vs. PC day $6,{ }^{\#} P<0.05$ vs. PC day $21, * * P<0.05$ vs. PS day 6 , $* * * P<0.05$ vs. PC day 6.

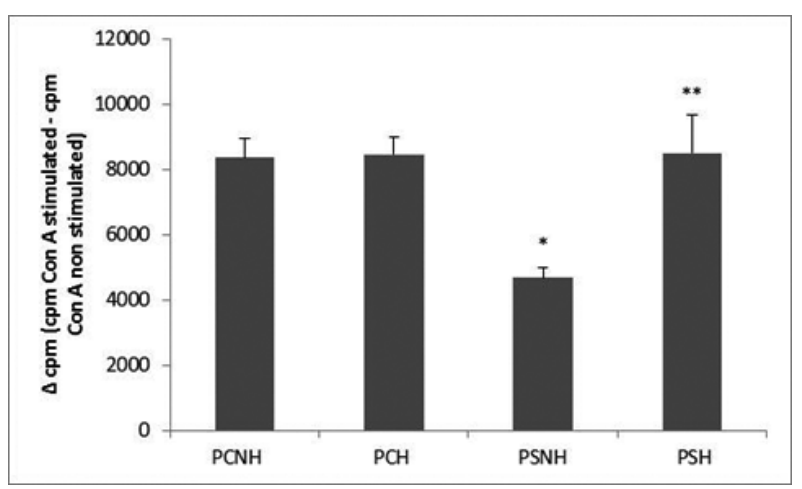

Figure 3. Effects of prenatal stress and postnatal handling on spleen lymphocytes $\mathrm{T}$ proliferation in animals subjected to postnatal stress: PCNH (n: 8), PCH (n: 8), PSNH (n: 8) and PSH (n: $8)$. Each bar represents the mean \pm SE. cpm: counts per million. $* P<0.05$ vs. $\mathrm{PCNH}, * * P<0.05$ vs. PSNH.

lymphocyte proliferation in PSNH animals compared with proliferation values of control PCNH group. In contrast, handling treatment ( $\mathrm{PSH}$ ) restituted $\mathrm{T}$ cells proliferation to values comparable to those in non-handled group (PSNH).

\section{INTERLEUKIN 2 LEVELS}

IL-2 is crucial for the maintenance of regulatory $\mathrm{T}$ cells and for the differentiation of $\mathrm{CD} 4^{+} \mathrm{T}$ cells into a defined effector T cell (Boyman and Sprent 2012). A decrease in IL-2 concentration was observed when the offspring was subjected to prenatal stress by IMO. Handling treatment reverted this effect in animals that were in control conditions (figure 4a) or with postnatal stress (figure 4b).

\section{DISCUSSION}

Environmental influences during pregnancy and early postnatal period may modulate neurobehavioral activity
A

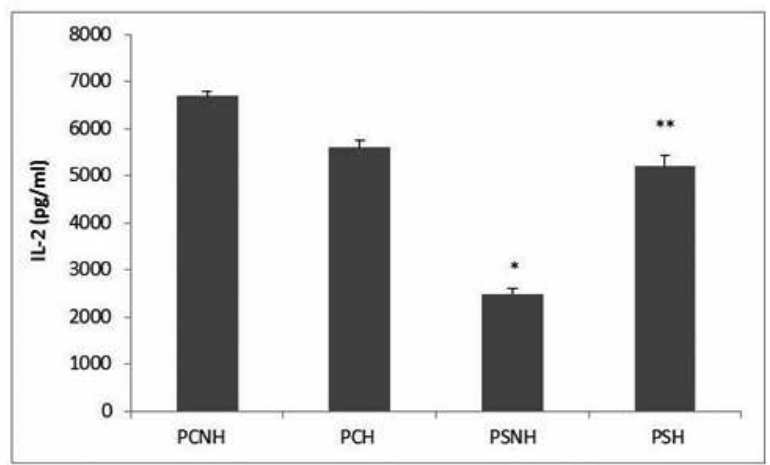

B

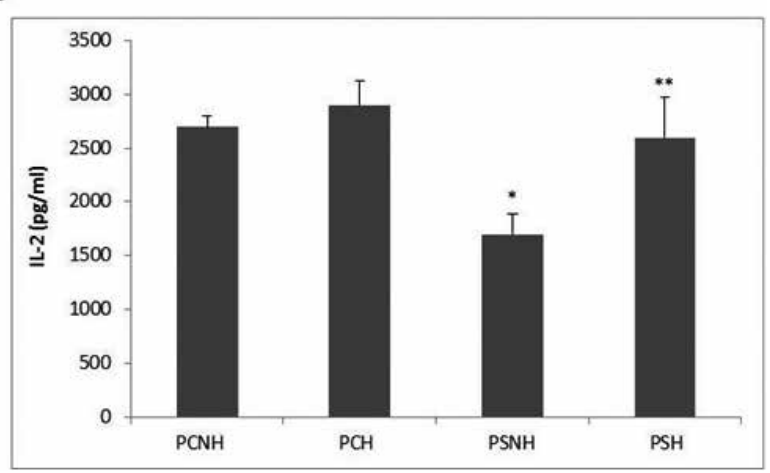

Figure 4. Effects of prenatal stress and postnatal handling on IL-2 level of animals subjected to control $(a)$ and stress $(b)$ postnatal treatment: PCNH (n: 5), PCH (n: 5), PSNH (n: 5) and PSH (n: 5). Each bar represents the mean \pm SE. $* P<0.05 v s$. PCNH, $* * P<0.05$ vs. PSNH.

in exposed individuals, effects that can last to adulthood. Early life is characterised by fast growth and execution of a precise developmental program based on epigenetic modifications, therefore it is a period particularly vulnerable to surrounding signals, such as psychosocial stimulation and maternal behavior (Desplats et al 2015). Animals exposed to prenatal stress or postnatal maternal deprivation (suboptimal maternal care, long time of separation) have enhanced neuroendocrine response to stress, increased levels of anxiety, depression-like behaviours and cognitive problems (Maccari et al 2014). Lemaire et al (2006) demonstrated that postnatal stimulations after delivery reduced the stress response in adult individuals. Additionally, Zhang et al (2012) indicated that neonatal handling and environmental enrichment enhance learning and memory of prenatally stressed offspring.

Several authors have demonstrated that prenatal stress is associated with increased plasma COR levels (D'mello et al 2006, Mayer et al 2011, Abdul Aziz et al 2012) and handling treatment reduces the hyperactivity of HPA axis produced by the first treatment (Liaudat et al 2012, Desplats et al 2015). Experimental evidence indicates that changes at epigenetic level are responsible for the reversion effects that postnatal tactile stimulation have on prenatal stressors consequences (Murgatroyd 
et al 2015). Recently published data showed that COR can pass through the placental barrier from the blood of a stressed pregnant female to the fetal circulation. In our study, close to the end of pregnancy (day 21), COR levels were higher in control pregnant rats compared with those in control animals at day 6 ; similar findings were reported by Brazao et al (2015). This result could be explained, at least in part, due to corticosterone concentration in the maternal plasma, the major circulating glucocorticoids in rats, which also increased as pregnancy progressed and are correlated with the number of live foetuses during the last 3 days of gestation (Dupouy et al 1975, Atkinson and Waddell 1995, Brãzao et al 2015). This association was also observed by Atkinson and Waddell (1995), when stressor was applied to pregnant females at the beginning of pregnancy (day 6), COR response to the stressor was more intense than that in pregnant rats close to the parturition (day 21), that could be explained, at least partially, by the documented hyporesponsiveness of HPA axis to stress in late pregnancy (Barlow et al 1973, Douglas et al 2003). High levels of this hormone in stressed pregnant rats can lead to a reduction in the number of mineralocorticoid receptors (MRs) but not glucocorticoid receptors (GRs) present in the hippocampus of the pups (Maccari et al 1995, Barbazanges et al 1996, Maccari et al 2003). Furthermore, MRs are usually the main substrates that exerts negative feedback control of adrenal glucocorticoid secretion under basal conditions (De Kloet and Reul 1987).

The consequences of prenatal stress and postnatal handling on the development of fetal immune system are not completely clarified. Immune cells, such as seen in other organs, express hormones and neurotransmitters receptors (Elenkov et al 2000). Hunk et al (1991) showed that activation of hormone receptors produces modulation of immune responses. An example is the constitutive expression of CD25, the IL-2 receptor $\alpha$-chain, which defines a distinct population of $\mathrm{CD}^{+} \mathrm{T}$ cells with suppressive activity in vitro and in vivo (de la Rosa 2004). Moreover, there is strong evidence indicating the involvement of the autonomic sympathetic system in modulating the activity of lymphocytes through specific receptors, which in turn trigger intracellular signaling mechanisms (Elenkov et al 2000). It has been suggested that inadequate communication between the neuroendocrine and immune system induce physiopathologies and immune disorders (Bakker et al 1995).

It has been found, in murine species, that the response of the immune system to conditions of chronic stress depends on increased COR secretion (Elenkov et al 2000). Our experimental analyses show that high basal COR concentrations in prenatal mothers produce immunosuppression in the offspring, indicated by impairment in T-cell mitogenesis. A similar effect was also found by Tuchscherer et al in 2002. Furthermore, results previously obtained in our laboratory indicate an inverse association between COR level and the activity of the immune system (Liaudat et al 2012). However, animal handling can restore $\mathrm{T}$ cell proliferation values to those observed in non-stressed controls.

High GC values not only influence $T$ cells proliferation but also modify the secretion of IL-2, since a decrease in both parameters was seen in prenatal animals. IL-2 is crucial for the maintenance of regulatory $\mathrm{T}$ cells and differentiation of $\mathrm{CD} 4^{+} \mathrm{T}$ cells into defined effector $\mathrm{T}$ cell subsets following antigen-mediated activation (Boyman and Sprent 2003). For $\mathrm{CD}^{+} \mathrm{T}$ cells, IL-2 signals both effector $\mathrm{T}$ cell generation and differentiation into memory cells. Our results agree with those previously reported by Fillion et al 1994. In accordance to this knowledge, epinephrine and corticosterone significantly altered mitogen-induced T-cell proliferation in response to different stress situations (Silberman et al 2003).

When prenatally stressed animals received postnatal stimulations, the immune parameters studied improved considerably. This effect is shown through the increase of $T$ cell proliferation and IL-2 secretion in animals with handling treatment. Similar results were found by Barabanova et al (2006), who showed that adaptation of animals to experimental conditions prevented the decrease in the number of IL-2 positive cells in the supraoptic nucleus after intranasal administration of Epithalon. Normalization of lymphocyte proliferation leads to adequate cellular immune response, which in conjunction with the mediating action of IL-2 would result in better protection against infections.

It is concluded that chronic prenatal exposure to a severe stressor such as IMO alters HPA axis activity as shown by the increased maternal COR concentration. Due to the relationship between neuroendocrine and immune system, prenatal stressed animals showed lower $\mathrm{T}$ cell proliferation and decreased IL-2 release. On the contrary, and being the novelty of this research, early postnatal stimulation reverses the effects of prenatal stress on the HPA axis, the proliferation of $\mathrm{T}$ lymphocytes and the concentration of IL-2 in response to the same stress condition.

\section{ACKNOWLEDGEMENTS}

The authors thank Prof. MSc Alexandra McCormack from Argentina, for performing the English language supervision.

\section{REFERENCES}

Abdul Aziz NH, Kendall DA, Pardon MC. 2012. Prenatal exposure to chronic mild stress increases corticosterone levels in the amniotic fluid and induces cognitive deficits in female offspring, improved by treatment with the antidepressant drug amitriptyline. Behav Brain Res 231, 29-39.

Armario A, Castellano JM. 1984. A simple procedure for direct corticosterone radioimmunoassay in the rat. Revista Española de Fisiologia 40, 437-442.

Atkinson HC, Waddell BJ. 1995. The hypothalamic-pituitary-adrenal axis in rat pregnancy and lactation: circadian variation and interrelationship of plasma adrenocorticotropin and corticosterone. Endocrinology 136,512-520. 
Bakker JM, Schmidt ED, Kroes H, Kavelaars A, Heijnen CJ, et al. 1995. Effects of short-term dexamethasone treatment during pregnancy on the development of the immune system and the hypothalamo-pituitary adrenal axis in the rat. $J$ Neuroimmunol 63, 183-191.

Barabanova SV, Artyukhina ZE, Kazakova TB, Khavinson VKh, Malinin VV, et al. 2006. Interleukin-2 concentration in hypothalamic structures of rats receiving peptides during mild stress. Bull Exp Biol Med 141, 390-393.

Barbazanges A, Vallé M, Mayo W, Day J, Simon H, et al. 1996. Early and later adoptions have different long-term effects on male rats offspring. J Neurosci 16, 7783-7790.

Barlow SM, Morrison PJ, Sullivan FM. 1974. Plasma corticosterone levels during pregnancy in the mouse. J Endocrinol 60, 473-483.

Bertuzzi ML, Bensi N, Mayer N, Niebylski A, Armario A, et al. 2003. Renal mechanisms involved in the stress-induced antinatriuresis and antidiuresis in rats. Arch Physiol Biochem 111, 59-264.

Boyman O, Sprent J. 2012. The role of interleukin-2 during homeostasis and activation of the immune system. Nat Rev Immunol 12, 180-190.

Brazão V, Kuehn CC, dos Santos CD, da Costa CM, Júnior JC, CarraroAbrahão AA. 2015. Endocrine and immune system interactions during pregnancy. Immunobiology 220, 42-47.

Benediktsson R, Calder AA, Edwards CR, Seckl JR. 1997. Placental 11 beta-hydroxysteroid dehydrogenase: a key regulator of fetal glucocorticoid exposure. Clin Endocrinol 46, 161-166.

Chen Cárdenas S, Mayer N, Romanini M, Rolando A, Liaudat A, et al. 2013. Reproductive response in offspring male rats exposed to prenatal stress and to early postnatal stimulation. Int J Morphol 31, 754-764.

Conrad CD. 2008. Chronic stress-induced hippocampal vulnerability: the glucocorticoid vulnerability hypothesis. Rev Neurosci 19, 395-411.

De Kloet E, Reul J. 1987. Feedback action and tonic influence and corticosteroids on brain function: A concept arising from and heterogeneity of brain receptor systems. Psychoneuroendocrinology 12, 83-105.

Desplats PA. 2015. Perinatal programming of neurodevelopment: epigenetic mechanisms and the prenatal shaping of the brain. $A d v$ Neurobio 10, 335-336.

D’Mello AP, Liu Y. 2006. Effects of maternal immobilization stress on birth weight and glucose homeostasis in the offspring. Psychoneuroendocrinology 31, 395-406.

Douglas AJ, Brunton PJ, Bosch OJ, Russell JA, Neumann ID. 2003. Neuroendocrine responses to stress in mice: hyporesponsiveness in pregnancy and parturition. Endocrinology 144, 5268-5276.

Dupouy JP, Coffigny H, Magre S. 1975. Maternal and foetal corticosterone levels during late pregnancy in rats. J Endocrinol 65, 347-352.

Elenkov IJ, Chrousos GP, Wilder RL. 2000. Neuroendocrine regulation of IL-12 and TNF-alpha/IL-10 balance. Clinical implications. Ann NY Acad Sci 917, 94-105.

Fenoglio KA, Brunson KL, Avishai-Eliner S, Stone BA, Kapadia BJ, et al. 2005. Enduring, handling-evoked enhancement of hippocampal memory function and glucocorticoid receptor expression involves activation of the corticotropin-releasing factor type 1 receptor. Endocrinology 146, 4090-4096.

Fillion L, Belles-Isles M, Lemyre L, Roy R. Reliability of lymphocyte proliferation assays. 1994. Stress Med 10, 43-48.
Iwasa T, Matsuzaki T, Munkhzaya M, Tungalagsuvd A, Kawami T, et al. 2014. Prenatal exposure to glucocorticoids affects body weight, serum leptin levels, and hypothalamic neuropeptide-Y expression in pre-pubertal female rat offspring. Int J Dev Neurosci 36, 1-4.

Keller-Wood M. 2015. Hypothalamic-pituitary-adrenal axis-feedback control. Compr Physiol 5, 1161-1182.

Landifield PW, McEwen BS, Sapolsky RM, Meaney MJ. 1996. Hippocampal cell death. Science 272, 1249b-1251b.

Li Y, P Gonzalez, Zhanga L. 2012. Fetal stress and programming of hypoxic/ischemic-sensitive phenotype in the neonatal brain: mechanisms and possible interventions. Prog Neurobiol 98, 145-165.

Liaudat A, Rodríguez N, Vivas A, Gauna H, Mayer N. 2012. Effect of early stimulation on some immune parameters in a model of prenatally stressed rats. Int J Phys Sci 4, 73-82.

Maccari S, Piazza P, Kabbaj M, Barbazanges A, Simon H, et al. 1995. Adoption reverses the long-term impairment in glucocorticoid feedback induced by prenatal stress. Neuroscience 15, 110-116.

Maccari S, Darnaudery M, Morley-Fletcher S, Zuena AR, Cinque C, et al. 2003. Prenatal stress and long-term consequences: implications of glucocorticoid hormones. Neurosci Biobehav Rev 27, 119-127.

Maccari S, Krugers HJ, Morley-Fletcher S, Szyf M, Brunton PJ. 2014. The consequences of early-life adversity: neurobiological, behavioural and epigenetic adaptations. J Neuroendocrinol 26, 707-723.

Malek TR. 2003. The main function of IL-2 is to promote the development of T regulatory cells. J Leukoc Biol 76, 961-965.

Mayer N, Greco C, Bertuzzi M, Rodriguez N, Vivas A, et al. 2011. Immobilization stress responses in adult rats exposed in utero to immobilization. Stress Health 27, e1-e10.

Meaney M, Aitken D, Sapolsky R. 1987. Thyroid hormones influence the development of hippocampal glucocorticoid receptors in the rat: a mechanism for the effects of postnatal handling on the development of the adrenocortical stress response. Neuroendocrinology 45, 278-283.

Merlot E, Couret D, Otten W. 2008. Prenatal stress, fetal imprinting and immunity. Brain Behav Immun 22, 42-51.

Michajlovskij N, Lichardus B, Kvetñasnsky R, Ponec J. 1988. Effect of acute and repeated immobilization stress on for and water urine output and vasopressin changes in rats. Endocrinol Exp 22, 143-157.

Murgatroyd C, Quinn JP, Sharp HM, Pickles A, Hill J. 2015. Effects of prenatal and postnatal depression, and maternal stroking, at the glucocorticoid receptor gene. Transl Psychiatry 5:e560; doi:10.1038/ tp.2014.140.

Tuchscherer M, Kanitz E, Otten W, Tuchscherer A. 2002. Effects of prenatal stress on cellular and humoral immune responses in neonatal pigs. Vet Immunol Immunopathol 86, 195-203.

Tuli JS, Smith JA, Morton DB. 1995. Corticosterone, adrenal and spleen weight in mice after tail bleeding, and its effect on nearby animals. Lab Anim 29, 90-95.

Veru F, Laplante DP, Luheshi G, King S. 2014. Prenatal maternal stress exposure and immune function in the offspring. Stress 17, 133-148.

Zhang Z, Zhang H, Du B, Chen Z. 2012. Neonatal handling and environmental enrichment increase the expression of GAP-43 in the hippocampus and promote cognitive abilities in prenatally stressed rat offspring. Neurosci Lett 522, 1-5. 